\title{
Preface: Book Building-Blocks
}

$I$

N MY PREVIOUS attempts at writing books, I cannot remember devoting much thought to how the text should be arranged. Ethnographic monographs with an ecological bent (Netting 1968, 198I) started naturally with chapters on physical environment and land use and finished with discussions of economic and social change. A textbook comparing different types of subsistence adaptation (Netting I977, 1986) went from hunting and gathering to intensive cultivation (while all the time denying an evolutionary approach). The chapters in this book on smallholder farming and households have been written over a longer period of time, in fits and starts, mainly during the summers of 1989 and 1990 , and then rearranged. Following the conventional, cut-and-dried scholarly saw "Theory comes first," I dutifully crammed definitions, generalizations, and critical appreciations of Ester Boserup, Malthus, and Marx into an early chapter and then went through some of the same procedures for the Chayanov model in a chapter following my own discussion of the farmfamily household. Some informed advice and further reflection persuaded me that my desired audience of students, environmentalists, international developers, and agricultural policy advisers, as well as academic geographers, historians, economists, and anthropologists, might well prefer to begin with the on-the-ground realities of actual farming systems, labor, and property. This approach reproduced in part my own inductive experience of learning about specific cases of intensive agricultural practices and their functional links to household organization and land tenure.

Chapter I on the technology and knowledge of intensive farm practices and Chapter 2 on the farm-family household identify and describe the smallholder system, contrasting it with extensive types of land use and such agrarian social arrangements as the estate, the plantation, and the commune. Chapters 3, 4, and 5 broaden the comparative framework to consider data drawn largely from the economics literature on labor time, 
energy exchange and sustainability, and farm size and productivity. I have tried to explain those awkward, counterintuitive findings that small farms regularly produce more per unit area than bigger farms in the same area, and that they do so with greater energy efficiency and less environmental degradation.

Chapter 6 enters the confused and thorny thicket of property and land tenure, in support of the claim that households of intensive cultivators necessarily hold private, heritable rights in some resources, while exercising well-defined, corporate common property rights in others. Such tenure institutions and the differential returns to labor and management in different household enterprises account in part for obvious inequalities among smallholders, the subject of Chapter 7. Both upward and downward economic mobility over the household developmental cycle and between generations reflect the persistent internal dynamism of smallholder societies. Some of the same factors suggest reasons for the failure of the market economy in general and capitalism in particular to polarize smallholders into rich landlords and a landless proletariat of workers. All of the themes of smallholder population, intensive agriculture, and household organization are reprised in a modest approach to the richly textured history of Chinese agriculture in Chapter 8 . The dramatic resurgence of the smallholder pattern in China after an era of socialist collectivization gives testimony to the essential social and economic soundness of the institution.

It may appear to be some sort of mock-populist arrogance or intellectual discrimination that causes me to shuffle the chapters on substantive theory to the back of the book. It is with no disrespect toward the great thinkers of the past and the present that I postponed my commentary on their ideas until after the evidence had been laid out. Rather it was owing to my own inability to come to grips with their more general and abstract formulations until I could measure them against some ethnographic and historic benchmarks. Those who feel more comfortable with an introduction presenting a theoretical context might want to skip immediately to Chapters 9 and 10 . The fact that my own mean approximations have been informed and refined throughout by my understanding of Boserup and Julian Steward, Marx and A. V. Chayanov, Clifford Geertz and Marshall Sahlins is too obvious to require comment.

I cannot honestly say that I embarked on field research to test welldefined hypotheses or to develop the propositions of a theoretical paradigm. Although operating under the loose appellation of cultural ecologist, I neither adopted the biologists' procedures of measuring energetic inputs and outputs in caloric terms (Rappaport 1971; Hardesty 1975; Lee 1969) nor applied ecosystemic models of equilibrium and cybernetic feedback 
loops (Vayda and Rappaport 1968; Flannery 1968; Rappaport 1968) with scientific rigor. Problems of both method and theory in translating biological models into human ecology have been recognized by John Bennett (1976), Roy Ellen (1982), P. J. Richerson (1977), Emilio Moran (1984, I990), and Benjamin Orlove (I980). My own orientation has been that of a rather pedestrian neofunctionalism, broadening the range of variables to include relevant factors of physical environment, population, land-use practices, and technology as they are interrelated with the social organization of agricultural production, and to suggest regularities of change through time in this system. Ecological functionalism need not be the analysis of a closed, static equilibrium system-it should instead be comparative and historical.

Theory became important to me inasmuch as it named concepts and provided generalizations of significant processes-for example, Steward's cultural ecology, Boserup's agricultural intensification and population pressure, Malthus's preventive checks, B. L. Turner and S. B. Brush's market demand, and Hans Binswanger's transaction costs in household and wage labor. Perhaps equally important to the effort of ethnological, cross-cultural comparison was my growing sense that certain theoretical positions seemed to run contrary to the accumulating evidence of the smallholder pattern. Marx appeared to neglect the role of demographic change and to substitute evolutionary conjectures about primitive communism for an understanding of the conditions that generate more individualized rights in property. The polarization of rural society into landowners and wage workers predicted by Lenin seemed not to take place among smallholders in a market economy (Hayami and Kikuchi 1982; White and Wiradi 1989; Eder 1990; Attwood 1992). Chayanov's emphasis on consumer/worker ratios and a subsistence economy isolated from the market and wage labor provided an ideal peasanthousehold type with few referents in the real world. Geertz's (1963, 1984) influential concept of involution restricted the range of adaptation that could take place in smallholder communities and attacked "economistic" explanation. Sahlins's (1972) domestic mode of production gave priority to kinship and political considerations and explicitly denied the role of "practical reason" in making sense of household farm production.

Perhaps most striking of all to me were the contradictions in the concept of global agricultural progress toward the unquestioned goal of industrialized, large-scale, scientific, energy-intensive, mechanized, specialized commodity-producing farms that dominated most development thinking in the half century after World War II. I touch on some of these issues in the concluding Epilogue. The theories of capitalist modernization and socialist revolution, often so different, appeared to be in implicit 


\section{$\mathrm{x}$ Preface}

agreement that the smallholder had to go. The emerging problems of the farm-as-factory model in maintaining food production, supporting environmental sustainability, reducing economic costs and risk, mobilizing efficient labor, and providing incentives now threaten both agribusiness industrial farms and rural collectives. In this book I frame a smallholder alternative.

R. McC. N. 